\title{
宇宙用テザーの残存率評価について*1 Survival Probability Assessment of Space Tethers
}

\author{
花田 俊 也 ${ }^{* 2} \cdot$ 平 山 寛 ${ }^{2} \cdot$ 大 石 篤 ${ }^{* 2} \cdot$ 田 中 陽 介 $^{* 2} \cdot$ 八坂哲 雄 ${ }^{* 2}$ \\ Toshiya Hanada, Hiroshi Hirayama, Atsushi Oishi, Yosuke Tanaka and Tetsuo Yasaka
}

Key Words : Space Engineering, Spacecraft, Artificial Satellite, Environment

\begin{abstract}
Space tethers are subject to high collision risk due to the very large collision cross-sectional area and they can be cut easily by impacts of small particles because of the thin diameter. Therefore, double-line tethers have been proposed to extend their life. The previous works assessed the survivability of double-line tether treated two wires independently. This treatment assumed that the distance between two wires is infinite. Physically, the distance between two wires is finite, however. Therefore, two wires could be cut simultaneously if the particle cutting through the first wire has or the remnant melted or vaporized at impact on the first wire have still enough energy to cut the second wire. As a result, unfortunately, once we consider that two wires can be cut simultaneously by a single impact, the merit of double-line tether disappears. Double line tether without sufficient clearance between two lines would not survive longer than expected. In this paper we will describe how to treat double line tether with a finite clearance between two lines and provide some results from applying this technique to a micro tether satellite named QTEX, being developed at Kyushu University.
\end{abstract}

\section{1. 緒言}

複数の衛星を細い「ひも (tether)」で繋ぐという概念は 1885 年ツィオルコフスキーによって提案された .「ひも」で 票がれた衛星群をテザー衛星と称し，これまでに以下のよ うな利用法が提案されてきだ1).

重力傾斜効果 : テザーの最大の利用法として挙げられる 地球の引力は距離の 2 乗に反比例して変化する一方, 遠心 力 (見かけの力) は距離に比例して変化するので, テザー のように細長い物体は受動的に長手方向が地球指向するこ とになる . 細かな姿勢制御は必要となるが従来よりも大幅 に衛星の姿勢制御か軽減されることになる。

高高度大気の観測 : 高度 100〜150 km を周回する衛星は 大気抵抗のため, 弚の軌道の寿命は極めて短いものとなる 弚こで, 片方の衛星を大気抵抗の少ない高度に待機させ，光 こからテザーを伸ばしもう片方の衛星を大気中に送り込む ことで兴の寿命を長期化することが可能となる .

多点同時観測 : 複数の観測器を連結したテザー衛星を用 いて同時刻に異なる高度での観測を行うことができる．例 えは地球磁場について, 水平方向の分布状況については広 く知られているが, 高度方向の分布状況はこれまで調査さ れた事例が少なかった .このためテザーを利用した地球磁 場の観測に期待が集まっている.

フォーメーション・フライト：衛星の編隊飛行を行う場

*1 C) 2006 日本航空宇宙学会

平成 16 年 7 月 $18 \sim 25$ 日, 第 35 回宇宙研究委員会総会におい て一部発表. 平成 17 年 10 月 26 日原稿受理

*2 国立大学法人九州大学大学院工学研究院航空宇宙工学部門
合, 各衛星の相対位置は時間とともに変化するので, 以前 は個別に軌道制御をする必要があった，しかし，各衛星を テザーて繋ぐことで，個別に軌道制御することなく編隊を 維持することができる．将来的には衛星間で電力供給を行 うことも計画されている.

軌道間エレベータ：テザーで繋がれた衛星間を宇宙機が テザーを手繰りながら移動するエレベータ・システムも提 案されている2).このようなシステムを利用すればロケッ トのように化学燃料を用いて直接相手側に接近しなくとも 物資の輸送，回収が可能である. 大型建造物の建設時には 予め展開しておいたテザーを伝って太陽電池パネルなどを 運搬できる．また，衛星間の移動中に異なる高度で科学観 測を行うこともできる .

軌道変換 : テザー衛星では, 質量中心より高い軌道にあ る衛星の軌道速度は本来の軌道速度よりも速く, また質量 中心より低い軌道にある衛星は本来の軌道速度よりも遅く 飛行していることになる.この状態においてテザーを突然 切り離すと, 高い軌道の衛星は切り離された地点を近地点 とする楕円軌道へ, また低い軌道の衛星は切り離された地 点を遠地点とする楕円軌道へ移行することができる．この 切り離しはテザーが安定した状態においても行えるが, 意 図的にシステムを回転させることで，より効果的に軌道変 換を行うことができる．またこの軌道変換を利用して，能 動的に大型の不要物体の高度を下げて除去することも提案 されている。

導電性テザー : 軌道傾斜角の小さい軌道ではテザーか地球 の磁場を横切るため, テザーの導電性が高ければ電磁誘導 作用により, 誘導起電圧が発生する . テザーの一端に電子 
銃を取り付ければテザーに継続して電流が流れ，発電を行 うことができる．これは運動エネルギーを電気エネルギー として取り出していると考えることができ, 発電を続けれ ばシステムの高度は次第に下がるというデメリットがある 一方，このデメリットを利用して，能動的に大型の不要物 体の高度を下げて除去することも提案されている33.

以上のように，多種多樣なテザーの利用法が提案・検討 されている.これらのテザーへのスペース・デブリの衝突を 考えるとき，テザーのような細い物体への衝突は一見少な いように思える . しかし , 細いテザーゆえに微小なスペー ス・デブリによっても切断される可能性がある上，スペー ス・デブリは小さくなればなるほど光の個数は指数関数的 に増える . またテザーはキロメートルのオーダーで用いる ことが多く，スペース・デブリ自体の大きさを考慮した有 効衝突断面積は大きなものになる (第 2 图参照). 兴の相乗 効果で, テザーのスペース・デブリによる切断は無視でき ないものとなる .

次節に詳細を述べるように, 九州大学でもテザー衛星の 開発を進めており，このテザー衛星のテザーも例外無く，ス ペース・デブリの衝突による切断が大きな問題となってい る.テザーが切断されれば，もはやテザー衛星としてのミッ ションは成立しないので, スペース・デブリ衝突に対する テザーの残存性は, テザー・システムの実用化に向けた重 要な検討事項となる .

九州大学におけるスペース・デブリ衝突に対するテザー 残存率の解析は, 西峯 ${ }^{4)}$ によって始められた . 西峯は 1 本 の「ひも」で構成されるシングル・テザーに対し，2 本の 「ひも」を用い, 要所要所に結び目を設けてループを構成す るダブル・テザー (第 3 図参照) を提案した . ダブル・テ ザーでは, 同じループ (結び目と結び目の間) にある 2 本 の「ひも」が 2 本とも切断されない限り，テザーとしては 機能することができる . 西峯はシングル・テザーとダブル . テザーの残存率を解析的に評価・比較し, ダブル・テザー の採用により残存率が大幅に増すことを示した ${ }^{4,5)}$.

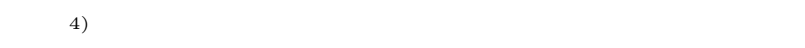
じループにある 2 本のテザーが同時に切断される確率を計 算する際に , スペース・デブリは 2 本のテザーのうちの一 方のテザーの中心を必ず通って，もう一方のテザーに衝突 すると仮定していた .この仮定では, ループの隙間が十分 に大きくないと，同じループにある 2 本のテザーが同時に 切断される場合の有効衝突断面積を過小に見積もる. 弚こ で大石 ${ }^{6}$ は , 同じループにある 2 本のテザーの質量中心を 原点とする極座標を考え，有効衝突断面積をより正確に見 積もる評価法を提案した . また , 大石はこの手法を用いて 国際スペース・デブリ調整委員会 (IADC) のタスクのひ とつである導電性テザーのミッション成功率7 9) を評価し た. 兴の結果，ループの隙間が十分に大きくないと, ダブ ル・テザーの延命効果は期待できないことを見出した ${ }^{6,10)}$

前述のように, 西峯の手法では同じループにある 2 本の テザーが同時に切断される確率を過小に見積る．言い換え れば， 2 本のテザーが別々に切断される確率を過大に見積
もることとなり，同じループにある 2 本のテザーが別々に 切断される場合のみを考慮して, ダブル・テザーの残存率 を算出した結果との差異は顕著ではなかった . 具体的には， ループを構成する 2 本のテザーを弚れ攵れ独立のシングル・ テザー・セグメントとして考え, 兴のシングル・テザーの年 間衝突回数からシングル・テザー・セグメントが $t$ 年後に切 断される本数を計算し，弚の本数によってダブル・テザー が切断されるシングル・テザー・セグメント切断の組合せの 発生する確率を積算してダブル・テザーの残存率を算出し ていた . 西峯の手法に対し, Hirayama ら ${ }^{11)}$ はダブル・テ ザーを構成するひとつのループの状態 ( 2 本残存, 1 本残存 1 本破断，2 本破断）に着目し，ループの状態遷移を確率論 的に記述する手法を提案した .この手法により，ループの 状態を支配する微分方程式を構築し，光の一般解から，時 間の連続関数として，任意の時刻のダブル・テザー全体の 残存率か容易に評価できるようになった．また Hirayama らはこの手法を用いた試算により，ひとつのループ内では 2 本のテザーが同時に切断されるよりも別々に切断される 確率が高い場合であっても，稀に起こる 2 本同時の切断に よってダブル・テザー全体としての破断に至ることが多い ことを見出した ${ }^{11)}$.

本論文では, 大石の有効衝突断面積の評価法 ${ }^{6)}$ と $\mathrm{Hi}-$ rayama らの残存率の確率論的評価法11) を組み合わせて 用い，九州大学で開発の進められているテザー衛星の残存 率を再評価した結果と得られた新知見について報告する .

\section{2. 超小型テザー衛星 QTEXについて}

九州大学におけるテザー研究は 1994 年から始められた . 研究開始当初はテザーを用いた理学系ミッション, 軌道変換 など樣々な応用分野についての研究が進められる一方, 並 行して小型テザー衛星の概念設計も行われた . 1997 年から は実際にピギーバック衛星 (相乗り衛星) として打上げを 目指した D-TES (Double Tethered Experimental Satellite) ${ }^{12)}$ の開発か開始された . D-TES は, ダブル・テザー技 術 (第 3 図参照) の実証, 簡易な制御法則によるテザー伸 展技術の確立, さらに科学技術プラットホームの提供など を谷の開発目的としていた . また，同時にD-TES プロジェ クトは, 九州大学において学生主導による衛星開発の在り 方を模索・検討しながら，衛星開発チームの構成，大学で の設計担当者のスムーズな引継ぎ方法を確立したものであ り, 現在に至る九州大学での衛星開発活動の基礎を築いた プロジェクトでもあった . 弚の後, D-TES の基本設計をも とに , 九州大学では新たに日米共同超小型テザー実験衛星 QUEST (Kyushu U.S. Experimental Satellite Tether) プロジェクト ${ }^{13 \sim 15)}$ が開始された . QUEST は日米大学合 同の宇宙システム・シンポジウム (USSS) の中で , 九州大 学とユタ州立大学, アリゾナ州立大学との共同開発という ことで 1998 年から開始され，1999 年からはユタ州立大学 に代わってサンタクララ大学が参画し, アリゾナ州立大学, サンタクララ大学, 九州大学の 3 大学での共同開発となっ た.当初，九州大学はテザー機構を担当していたが, 米国 
第 1 表 QTEX 主要諸元

\begin{tabular}{lc}
\hline \multicolumn{1}{c}{ 主要諸元 } \\
\hline 寸法 & 母機 : $480 \times 480 \times 250 \mathrm{~mm}$ \\
子機 : $480 \times 480 \times 250 \mathrm{~mm}$
\end{tabular}

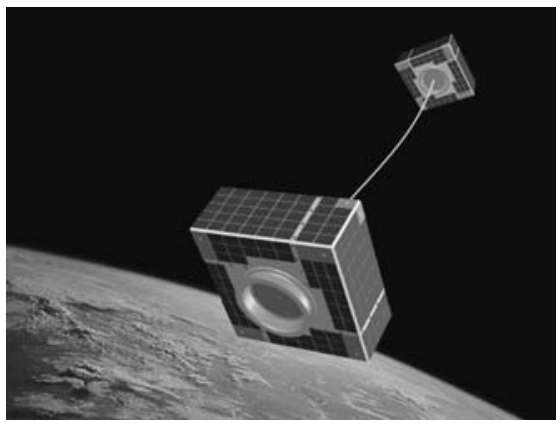

第1図 QTEX 外観図

からの技術移転に規制があり，共同開発が困難となったた め, 2003 年に, 衛星全システムを九州大学独自て設計・開 発することを目的に新たな小型テザー衛星開発プロジェク トとして QTEX ${ }^{16,17)}$ を立ち上げた .

QTEX は今までの基礎研究, 各プロジェクトの成果を活 かし, 2003 年から本格的に開発を開始した . 2003 年から は学生の手による BBM の設計・製作を実施すると共に, 構 造，熱設計などのシステム解析を進め，さらに 2004 年から は, 産学官連合グループ九州小型衛星プロジェクト (QPS) 研究会と協力し, 上記の BBM を基に企業との EM 共同開 発を進め, 2005 年 10 月現在, EM 製作・試験段階にある。

第 1 表の主要諸元および第 1 図の外観図に示すように， QTEX は直径 $0.33 \mathrm{~mm}$ ，長さ $2 \mathrm{~km}$ のテザーで繋がれた母 機および子機から構成され，母機，子機は両者ともに $50 \mathrm{~cm}$ $\times 50 \mathrm{~cm} \times 20 \mathrm{~cm}$, 約 $20 \mathrm{~kg}$ の直方体の形をしている .

\section{3. 計 算 手 法}

3.1 テザーの切断率

3.1 .1 シングル・テザー 第 2 図に示すように , シング ル・テザーは, テザーの直径 $D_{\mathrm{T}}$ と比べて, 乥のサイズ $d$ が $d_{\mathrm{C}}$ 以上のスペース・デブリの一端がテザーの中心から 距離 $D_{\mathrm{TC}} / 2$ 以内に衝突したら，切断すると仮定する．よっ

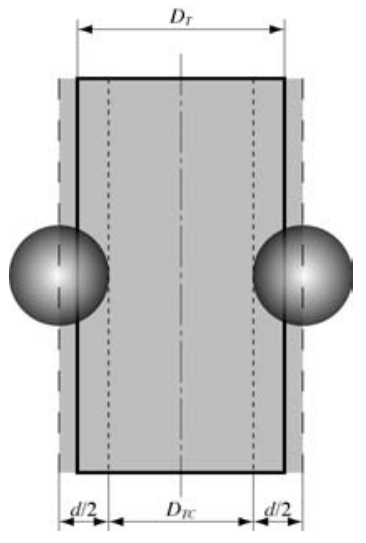

第 2 図 有効衝突断面積

て , テザーの長さを $L$ とすると，有効衝突断面積は

$$
A(d)=L\left(D_{\mathrm{TC}}+d\right)
$$

で与えられる．

切断率 (年間切断回数) は式 (1) で与えられる有効衝突 断面積に , サイズ $d$ のスペース・デブリのフラックスを乗 じてサイズ $d_{\mathrm{C}}$ から無限大 (実際は $1 \mathrm{~m}$ ) まで積分すれば 得られる.すなわち

$$
R_{\mathrm{F}}=\int_{d_{\mathrm{C}}}^{\infty} A(d) \mathrm{d} \varphi(d)
$$

また , シングル・テザーが $t$ 年後に切断されずに残存して いる確率 $X(t)$ は

$$
X(t)=X(0) \exp \left(-R_{\mathrm{F}} t\right)
$$

で与えられる.なお， $X(0)$ は $t=0$ における初期值である . 本論文では, 式 (2) を積分するために次の手法を導入し ている.

1) サイズ $d$ のスペース・デブリのフラックスをサイズ $d$ 以上のスペース・デブリの累積フラックス $\Phi(d)$ を用いて 記述する．すなわち

$$
\Delta \varphi(d)=\Phi(d)-\Phi(d+\Delta d)
$$

2) サイズ $d$ 以上のスペース・デブリの累積フラックス は, 両対数グラフ上 (第 6 図参照) の任意の区間で線形近 似できる . すなわち

$$
\log _{10} \Phi(\chi)=a \chi+b
$$

ただし

$$
\chi=\log _{10} d
$$

また，任意の区間を $\left(\chi_{i}, \chi_{i+1}\right)=\left(\log _{10} d_{i}, \log _{10} d_{i+1}\right)$ と すると定数 $a$ および $b$ は

$$
a=\frac{\log _{10}\left(\Phi\left(d_{i+1}\right) / \Phi\left(d_{i}\right)\right)}{\log _{10}\left(d_{i+1} / d_{i}\right)}
$$




$$
b=\frac{\log _{10} d_{i+1} \log _{10} \Phi\left(d_{i}\right)-\log _{10} d_{i} \log _{10} \Phi\left(d_{i+1}\right)}{\log _{10}\left(d_{i+1} / d_{i}\right)}
$$

で与えられる . 式 (2) に式 (6) の座標変換を適用し，さら に積分区間を分割すれば

$$
R_{\mathrm{F}}=\int_{\chi_{\mathrm{C}}}^{\infty} A(\chi) \mathrm{d} \varphi(\chi)=\sum_{i=0}^{\infty} \int_{\chi_{i}}^{\chi_{i+1}} A(\chi) \mathrm{d} \varphi(\chi)
$$

が得られる・ただし $\chi_{0}=\chi_{\mathrm{C}}=\log _{10} d_{\mathrm{C}} \cdot$ また , 式 (4) と 式(5)から

$$
\begin{aligned}
\Delta \varphi(\chi) & =\Phi(\chi)-\Phi(\chi+\Delta \chi) \\
& =-\frac{\mathrm{d} \Phi(\chi)}{\mathrm{d} \chi} \Delta \chi \\
& =-(a \log 10) 10^{a \chi+b} \Delta \chi
\end{aligned}
$$

式 (10) を式 (9) の積分に代入し, 積分区間 $\left(\chi_{i}, \chi_{i+1}\right)$ に ついて解析的に積分すると

$$
\begin{aligned}
\int_{\chi_{i}}^{\chi_{i+1}} A(\chi) \mathrm{d} \varphi(\chi) & \int_{\chi_{i+1}}^{\chi_{i}} L\left(D_{\mathrm{TC}}+10^{\chi}\right)(a \log 10) 10^{a \chi+b} \mathrm{~d} \chi \\
= & L\left[D_{\mathrm{TC}}\left(\Phi\left(\chi_{i}\right)-\Phi\left(\chi_{i+1}\right)\right)\right. \\
& \left.+\frac{a}{1+a}\left(10^{\chi_{i}} \Phi\left(\chi_{i}\right)-10^{\chi_{i+1}} \Phi\left(\chi_{i+1}\right)\right)\right] \\
= & L\left[D_{\mathrm{TC}}\left(\Phi\left(d_{i}\right)-\Phi\left(d_{i+1}\right)\right)\right. \\
& \left.+\frac{a}{1+a}\left(d_{i} \Phi\left(d_{i}\right)-d_{i+1} \Phi\left(d_{i+1}\right)\right)\right]
\end{aligned}
$$

式 (11) を式 (9) に代入すると，最終的に切断率は

$$
\begin{aligned}
R_{\mathrm{F}}= & \sum_{i=0}^{\infty} L\left[D_{\mathrm{TC}}\left(\Phi\left(d_{i}\right)-\Phi\left(d_{i+1}\right)\right)\right. \\
& \left.+\frac{a}{1+a}\left(d_{i} \Phi\left(d_{i}\right)-d_{i+1} \Phi\left(d_{i+1}\right)\right)\right] \\
= & L D_{\mathrm{TC}} \Phi\left(d_{\mathrm{C}}\right) \\
& +L \sum_{i=0}^{\infty} \frac{a}{1+a}\left(d_{i} \Phi\left(d_{i}\right)-d_{i+1} \Phi\left(d_{i+1}\right)\right)
\end{aligned}
$$

で与えられる．ただし $\Phi\left(d_{\infty}\right)=0$.

3.1 .2 ダブル・テザー 本論文では, ダブル・テザーの 切断率を評価するにあたり，第 3 図に示すようなダブル . テザーを仮定している.第 3 図では，ダブル・テザーの結 び目は, 直径 $2.5 D_{\mathrm{T}}$, 長さ $3.0 D_{\mathrm{T}}$ の円柱として簡略化さ れている.また，結び目と結び目の間をループと称し，光 の距離を $L_{\mathrm{S}}$ ，ループを構成する 2 本のテザーの隙間を $h$ (ループ間一定と仮定) としている.このダブル・テザーが 切断されるという事象は, 以下のサブ事象に分類される .

1) 結び目が切断される.

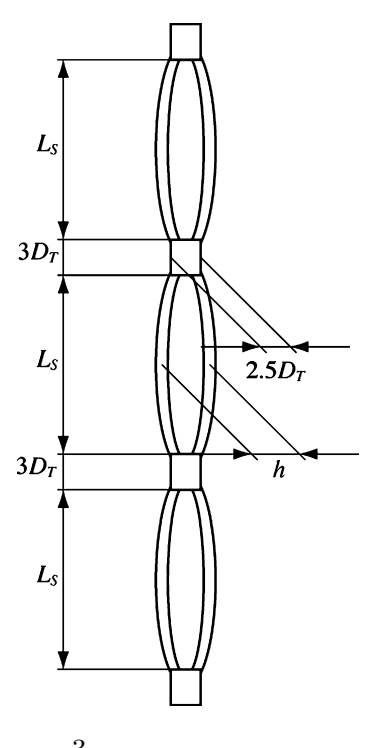

2) 2 本のテザーが同時に切断される .

3) 2 本のテザーが別々に切断される.

結び目の切断率は, シングル・テザーと同樣に計算する ことができる . 光の有効衝突断面積は式 (1) において $L$,

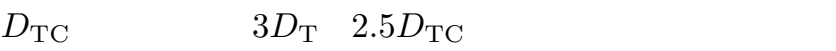
わち

$$
A_{\text {knot }}(d)=3 D_{\mathrm{T}}\left(2.5 D_{\mathrm{TC}}+d\right)
$$

また結び目の切断率も，式 (12) において $L, D_{\mathrm{TC}}$ を弚れ

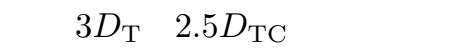

$$
\begin{aligned}
R_{\mathrm{Fknot}}= & \int_{2.5 d_{\mathrm{C}}}^{\infty} A_{\mathrm{knot}}(d) \mathrm{d} \varphi(d) \\
= & 3 D_{\mathrm{T}} \times 2.5 D_{\mathrm{TC}} \Phi\left(2.5 d_{\mathrm{C}}\right) \\
& +3 D_{\mathrm{T}} \sum_{i=0}^{\infty} \frac{a}{1+a}\left(d_{i} \Phi\left(d_{i}\right)-d_{i+1} \Phi\left(d_{i+1}\right)\right)
\end{aligned}
$$

を得る.ただし $d_{0}=2.5 d_{\mathrm{C}}$.

2 本のテザーが同時に切断される場合の切断率，または 別々に切断される場合の切断率を計算するためには，第 4 図および第 5 図に示すように , ダブル・テザーに対するス ペース・デブリの入射角を考慮しなければならない．

まず， 2 本のテザーが同時に切断される場合を考える．ス ペース・デブリのサイズが $h-D_{\mathrm{TC}}$ より大きい場合は , 第 4 図に示すようにスペース・デブリの入射角 $\theta$ に依存する ことなく, 2 本のテザーが同時に切断され得る領域が存在 する. 兴の領域は $L_{\mathrm{S}}\left(D_{\mathrm{TC}}+d-h \sin \theta\right)$ で与えられるの で, 2 本のテザーが同時に切断される場合の有効衝突断面 積は次のように求まる.

$$
\begin{aligned}
A_{20}(d) & =\frac{2}{\pi} \int_{0}^{\pi / 2} L_{\mathrm{S}}\left(D_{\mathrm{TC}}+d-h \sin \theta\right) \mathrm{d} \theta \\
& =L_{\mathrm{S}}\left(D_{\mathrm{TC}}+d-\frac{2}{\pi} h\right)
\end{aligned}
$$



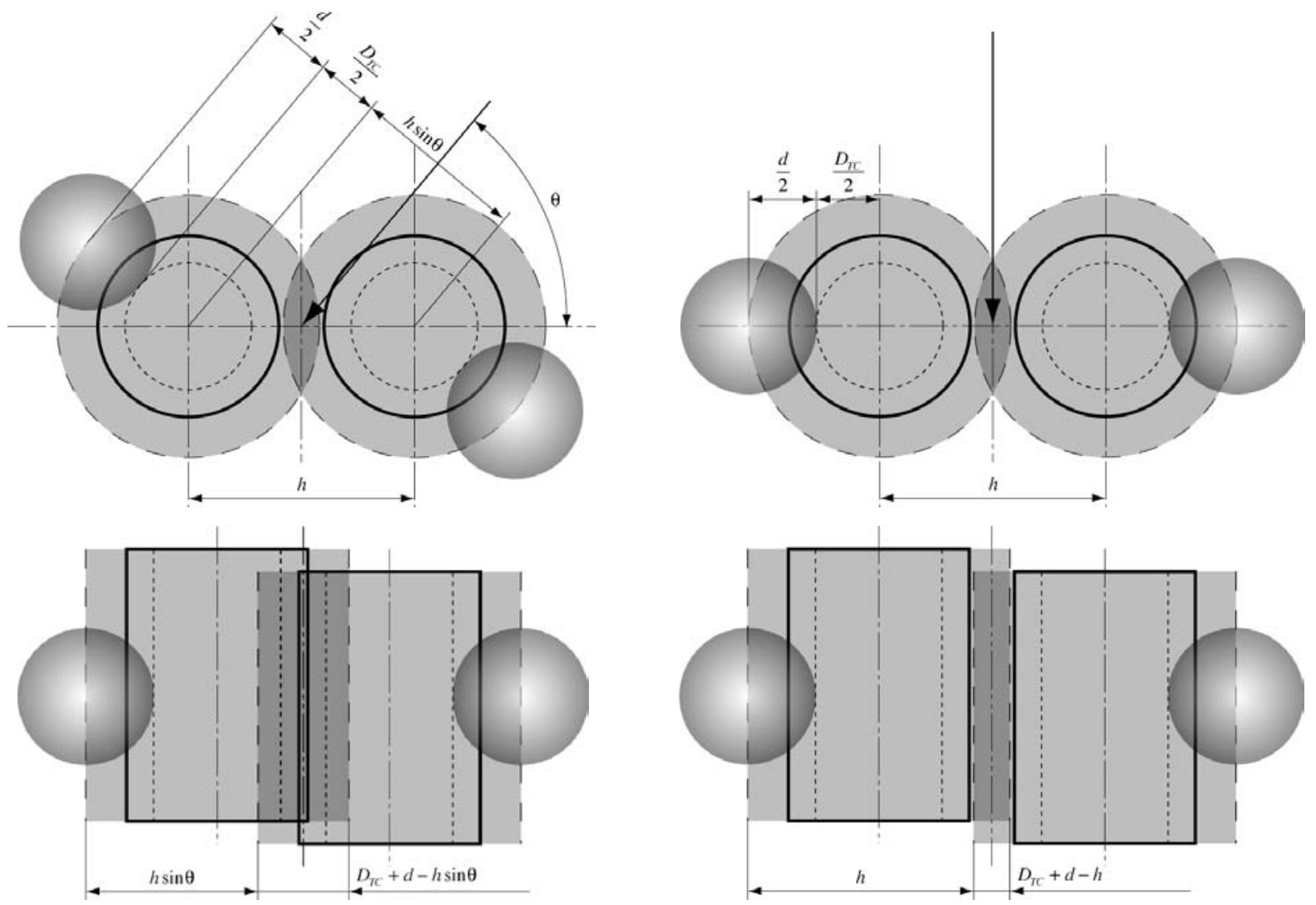

第 4 図 スペース・デブリの入射角と有効衝突断面積の関係 $\left(d>h-D_{\mathrm{TC}}\right)$
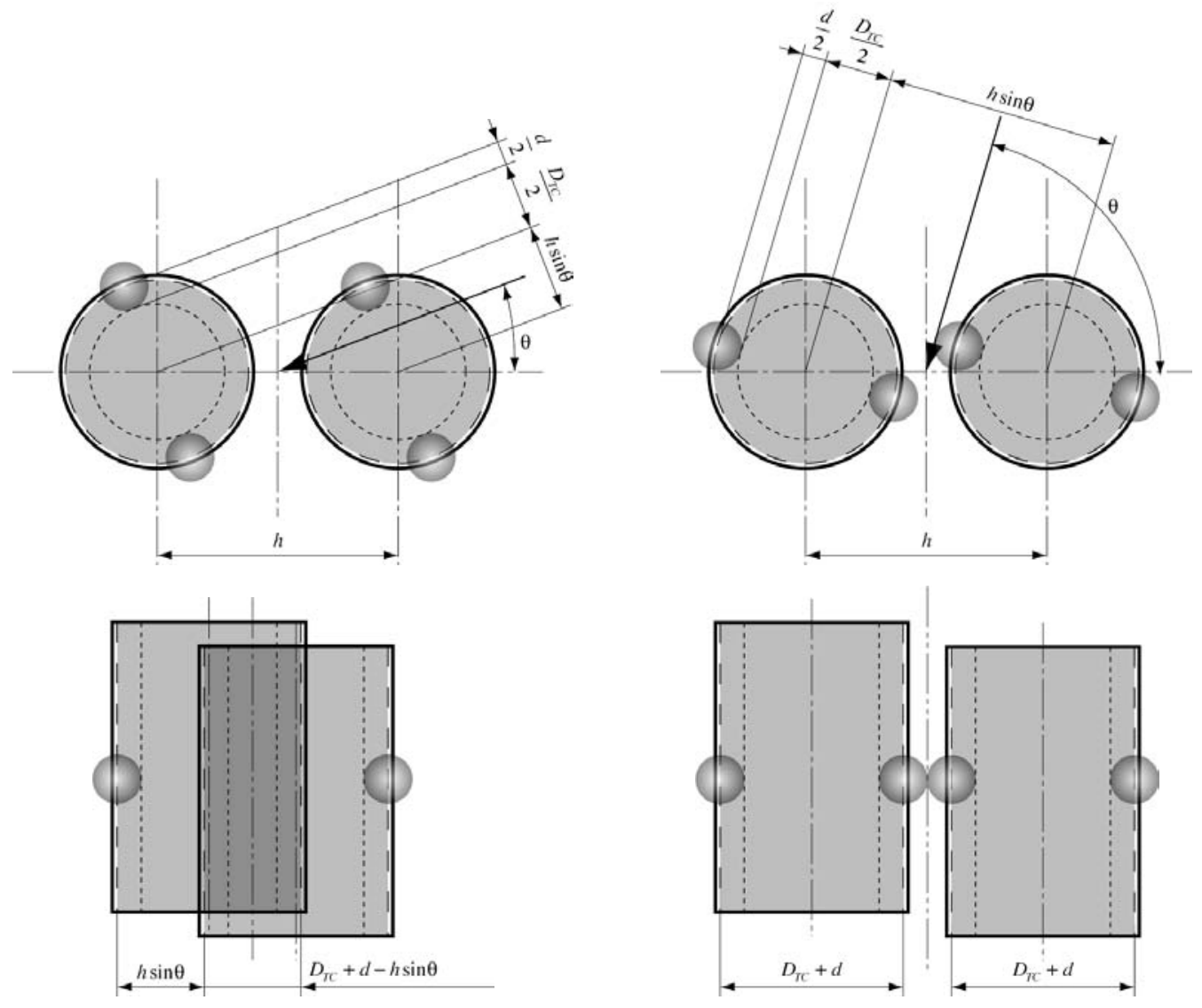

第 5 図 スペース・デブリの入射角と有効衝突断面積の関係 $\left(d<h-D_{\mathrm{TC}}\right)$ 
次に , スペース・デブリのサイズが $h-D_{\mathrm{TC}}$ より小さい場 合は, スペース・デブリの入射角が

$$
0 \leq \theta \leq \sin ^{-1} \frac{D_{\mathrm{TC}}+d}{h}\left(\equiv \theta_{\mathrm{C}}\right)
$$

を満たす場合にのみ，2 本のテザーが同時に切断され得る よって, 式 $(15)$ の積分区間を $(0, \pi / 2)$ から $\left(0, \theta_{\mathrm{C}}\right)$ に変 えて積分すればよい．

$$
\begin{aligned}
A_{20}(d) & =\frac{2}{\pi} \int_{0}^{\theta_{\mathrm{C}}} L_{\mathrm{S}}\left(D_{\mathrm{TC}}+d-h \sin \theta\right) \mathrm{d} \theta \\
& =\frac{2}{\pi} L_{\mathrm{S}}\left[\left(D_{\mathrm{TC}}+d\right) \theta_{\mathrm{C}}+h\left(1-\cos \theta_{\mathrm{C}}\right)\right]
\end{aligned}
$$

同樣にして，2 本のテザーが別々に切断される場合の有 効衝突断面積も計算できる . スペース・デブリのサイズが $h-D_{\mathrm{TC}}$ より大きい場合は, 2 本のテザーが別々に切断さ れ得る領域は $L_{\mathrm{S}} \times 2 h \sin \theta$ で与えられるので, 光の有効衝 突断面積は次のように求まる.

$$
A_{21}(d)=\frac{2}{\pi} \int_{0}^{\pi / 2} L_{\mathrm{S}} \times 2 h \sin \theta \mathrm{d} \theta=L_{\mathrm{S}} \times \frac{4}{\pi} h
$$

次に , スペース・デブリのサイズが $h-D_{\mathrm{TC}}$ より小さい場 合は, デブリの入射角が $\theta_{\mathrm{C}}$ を越えると 2 本のテザーが同 時に切断されないので, 2 本のテザーは必ず別々に切断さ れる.このことを加味して有効衝突断面積は次のように計 算できる .

$$
\begin{aligned}
A_{21}(d)= & \frac{2}{\pi}\left[\int_{0}^{\theta_{\mathrm{C}}} L_{\mathrm{S}} \times 2 h \sin \theta \mathrm{d} \theta\right. \\
& \left.+\int_{\theta_{\mathrm{C}}}^{\pi / 2} L_{\mathrm{S}} \times 2\left(D_{\mathrm{TC}}+d\right) \mathrm{d} \theta\right] \\
= & L_{\mathrm{S}} \times \frac{4}{\pi}\left[\left(D_{\mathrm{TC}}+d\right)\left(\frac{\pi}{2}-\theta_{\mathrm{C}}\right)+h\left(1-\cos \theta_{\mathrm{C}}\right)\right]
\end{aligned}
$$

2 本のテザーが同時に切断される場合の切断率 , または 別々に切断される場合の切断率は, 有効衝突断面積がスペー ス・デブリの入射角に依存するため，シングル・テザーの 切断率のように計算できないが, 2 本のテザーが同時に切 断される場合の有効衝突断面積は, シングル・テザーの有 効衝突断面積 $A_{\mathrm{S}}(d)$ と 2 本のテザーが別々に切断される場 合の有効衝突断面積を用いて $A_{20}(d)=A_{\mathrm{S}}(d)-A_{21}(d) / 2$ と記述できるので， 2 本のテザーが同時に切断される場合 の切断率, $R_{\mathrm{F} 20}$ ，は , シングル・テザーの切断率と 2 本の テザーが別々に切断される場合の切断率， $R_{\mathrm{F} 21}$ ，を用いて

$$
R_{\mathrm{F} 20}=R_{\mathrm{FS}}-\frac{R_{\mathrm{F} 21}}{2}
$$

で計算できる．したがって， 2 本のテザーが同時に切断さ れる場合の切断率を計算するために，別途关の積分をする 必要はない.ただし $R_{\mathrm{FS}}=R_{\mathrm{F}} L_{\mathrm{S}} / L$.

$d_{\mathrm{C}}$ が $h-D_{\mathrm{TC}}$ より大きい場合は，2 本のテザーが別々 に切断される場合の切断率は $A_{21}(d)$ が $\theta_{\mathrm{C}}$ に依存しないの
で , シングル・テザーの切断率の積分と同樣に解析的に積 分できる・よって

$$
R_{\mathrm{F} 21}=L_{\mathrm{S}} \times \frac{4}{\pi} h \Phi\left(d_{\mathrm{C}}\right)
$$

$d_{\mathrm{C}}$ が $h-D_{\mathrm{TC}}$ より小さい場合は , 積分区間を次のよう にふたつに分けなければならない .

$$
R_{\mathrm{F} 21}=\int_{d_{\mathrm{C}}}^{h-D_{\mathrm{TC}}} A_{21}(d) \mathrm{d} \varphi(d)+\int_{h-D_{\mathrm{TC}}}^{\infty} A_{21}(d) \mathrm{d} \varphi(d)
$$

第 2 項の積分区間では $A_{21}(d)$ が $\theta_{\mathrm{C}}$ に依存しないので，第 2 項の積分はシングル・テザーの切断率の積分と同樣に解析 的に積分できるが，第 1 項の積分区間では $A_{21}(d)$ が $\theta_{\mathrm{C}}$ に 依存するため，解析的に積分できない．よって，第 1 項の 積分は, 台形公式を適用して数値的に積分した．弚の結果

$$
\begin{aligned}
R_{\mathrm{F} 21}= & \frac{\log 10}{2} \sum_{i=0}^{N-1} a\left(A_{21}\left(d_{i}\right) \Phi\left(d_{i}\right)+A_{21}\left(d_{i+1}\right) \Phi\left(d_{i+1}\right)\right) \\
& \times \log _{10}\left(\frac{d_{i}}{d_{i+1}}\right)+L_{\mathrm{S}} \times \frac{4}{\pi} h \Phi\left(h-D_{\mathrm{TC}}\right)
\end{aligned}
$$

を得る．ただし， $d_{0}=d_{\mathrm{C}}, d_{\mathrm{N}}=h-D_{\mathrm{TC}}$.

\section{2 テザーの残存率}

3.2 .1 確率過程と確率状態変数による表現 ダブル・テ ザーの任意のひとつのループ (結び目と結び目の間) に注 目すると，光の区間に残っているテザー本数に応じて 状態 $2: 2$ 本とも残存している.

状態 $1: 1$ 本が切断され, 1 本が残存している.

状態 $0: 2$ 本とも切断されている.

の 3 通りの状態が考えられる. 弚して，ミッション開始時 に状態 2 であったものが，ある確率で 1 本ずつ切断されて 状態 1 を経て状態 0 人，あるいは 2 本同時に切断されて状 態 2 から直接状態 0 へ遷移してダブル・テザーとしての切 断に至る .この過程は以下に示すように確率過程として記 述できる。

ある時刻 $t$ において, ダブル・テザーの任意のひとつの ループが状態 $2,1,0$ である確率を光れ午れ $X_{2}(t), X_{1}(t)$, $X_{0}(t)$ という確率状態変数で表す. 定義より

$$
X_{2}(t)+X_{1}(t)+X_{0}(t)=1
$$

となる

状態 $i$ から状態 $j$ へ遷移する割合は, 時間の単位を年と すれば $R_{\mathrm{F} i j}$ （ただし $R_{\mathrm{F} 10}=R_{\mathrm{FS}}$ ）に等しいので, 確率状 態変数の推移は次の 2 元連立微分方程式に従う.

$$
\begin{aligned}
& \frac{\mathrm{d} X_{2}(t)}{\mathrm{d} t}=-\left(R_{\mathrm{F} 20}+R_{\mathrm{F} 21}\right) X_{2}(t) \\
& \frac{\mathrm{d} X_{1}(t)}{\mathrm{d} t}=R_{\mathrm{F} 21} X_{2}(t)-R_{\mathrm{F} 10} X_{1}(t)
\end{aligned}
$$

遷移率 $R_{\mathrm{F} i j}$ は軌道と時間の関数であるが，計算期間内 において軌道の変化やスペース・デブリ環境の変化が十分 
小さいならば， $R_{\mathrm{F} i j}$ を定数と見なして，微分方程式 $(25)$ の一般解を求めると

$$
\begin{aligned}
X_{2}(t)= & X_{2}(0) \exp \left[-\left(R_{\mathrm{F} 20}+R_{\mathrm{F} 21}\right) t\right] \\
X_{1}(t)= & {\left[X_{1}(0)+\frac{R_{\mathrm{F} 21}}{R_{\mathrm{F} 20}+R_{\mathrm{F} 21}-R_{\mathrm{F} 10}} X_{2}(0)\right.} \\
& \left.\times\left(1-\exp \left[-\left(R_{\mathrm{F} 20}+R_{\mathrm{F} 21}-R_{\mathrm{F} 10}\right) t\right]\right)\right] \\
& \times \exp \left[-R_{\mathrm{F} 10} t\right]
\end{aligned}
$$

となる．したがって，時刻 $t$ においてダブル・テザーの任 意のひとつのループが残存している確率は

$$
\begin{aligned}
X_{2}(t) & +X_{1}(t) \\
= & {\left[X_{1}(0)+X_{2}(0)\right.} \\
& \left.\times \frac{R_{\mathrm{F} 21}+\left(R_{\mathrm{F} 20}-R_{\mathrm{F} 10}\right) \exp \left[-\left(R_{\mathrm{F} 20}+R_{\mathrm{F} 21}-R_{\mathrm{F} 10}\right) t\right]}{R_{\mathrm{F} 20}+R_{\mathrm{F} 21}-R_{\mathrm{F} 10}}\right] \\
& \times \exp \left[-R_{\mathrm{F} 10} t\right]
\end{aligned}
$$

である .ここで, $X_{2}(0)$ および $X_{1}(0)$ は $t=0$ における初 期值で, ミッション開始時を $t=0$ とすれば

$$
\begin{aligned}
& X_{2}(0)=1 \\
& X_{1}(0)=0
\end{aligned}
$$

とおける，なお，式 (20) を加味すると，式 $(26)$ と (27) は 弚れ午れ次のように簡単化される。

$$
\begin{aligned}
X_{2}(t)= & X_{2}(0) \exp \left[-\left(\frac{R_{\mathrm{F} 21}}{2}+R_{\mathrm{F} 10}\right) t\right] \\
X_{1}(t)= & {\left[X_{1}(0)+2 X_{2}(0)\left(1-\exp \left[-\frac{R_{\mathrm{F} 21}}{2} t\right]\right)\right] } \\
\times \exp \left[-R_{\mathrm{F} 10} t\right] & (29) \\
X_{2}(t)+X_{1}(t)= & {\left[X_{1}(0)+X_{2}(0)\left(2-\exp \left[-\frac{R_{\mathrm{F} 21}}{2} t\right]\right)\right] } \\
& \times \exp \left[-R_{\mathrm{F} 10} t\right]
\end{aligned}
$$

3.2 .2 ダブル・テザー全体の残存率 ダブル・テザー全 体における，結び目の個数を $N$ (よって，結び目と結び目 の間のループの個数は $N+1)$ とする . ダブル・テザーの 各ループの高度差により，厳密にはスペース・デブリ環境 に差があるが, 差は十分小さいと仮定し，すべてのループ が式 (29) の確率状態変数に従うとする .

時刻 $t$ において , ダブル・テザーの任意のひとつのルー プカ残存している確率は $X_{2}(t)+X_{1}(t)$ で与えられるので, $N+1$ 個のすべてのループが残存している確率は

$$
\left(X_{2}(t)+X_{1}(t)\right)^{N+1}
$$

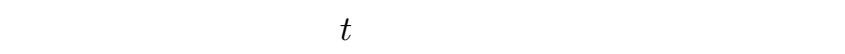
が残存している確率は

$$
X_{\text {knot }}(t)=X_{\text {knot }}(0) \exp \left[-R_{\text {Fknot }} t\right]
$$

で与えられるので,$N$ 個すべての結び目が残存している確
率は

$$
\left(X_{\mathrm{knot}}(t)\right)^{N}
$$

で求まる・したがって，ダブル・テザー全体の残存率は

$$
\left(X_{2}(t)+X_{1}(t)\right)^{N+1}\left(X_{\text {knot }}(t)\right)^{N}
$$

で与えられる．

3.2.3 $h \rightarrow \infty$ におけるダブル・ テザーの残存率 西峯 ${ }^{4}$ のように，ループを構成する 2 本のテザーを光れ光れ独立 のシングル・テザーとして取り扱う手法は, Pardini ら ${ }^{18)}$ によっても提案されている.この手法は, 言い換えれば, 2 本のテザーが形成するループの隙間を無限と仮定している ことになる.これに対し, 本論文では, 前述のようにルー プの隙間を有限としている. 実際問題として , ループの隙 間の違いによってダブル・テザーの残存率がどのように変 化するかを検討する際に, ダブル・テザーの残存率の最大 值として参照できるように , ループの隙間を無限とする場 合についても検討する .

ループの隙間が無限のとき，すべてのスペース・デブリ は，この陌間よりも小さいと考えられる．よって，有効衝 突断面積 $A_{20}(d)$ および $A_{21}(d)$ は，光れ光れ式 (15) およ び式 (19) で評価される .ところが, 式 (16)により $\theta_{\mathrm{C}}=0$ となるので, これを式 (15) および式 (19) に代入して評価 すると

$$
\begin{aligned}
& A_{20}(d)=0 \\
& A_{21}(d)=2 L_{\mathrm{S}}\left(D_{\mathrm{TC}}+d\right)=2 A_{\mathrm{S}}(d)
\end{aligned}
$$

となる．したがって

$$
\begin{aligned}
& R_{\mathrm{F} 20}=0 \\
& R_{\mathrm{F} 21}=2 R_{\mathrm{FS}}\left(=2 R_{\mathrm{F} 10}\right)
\end{aligned}
$$

すなわち, ループの隙間を無限とすることは, 2 本のテザー が同時に切断されないことを意味する . 式 (36) を式 (29) および式 (30) に代入すると

$$
\begin{aligned}
X_{2}(t)= & X_{2}(0) \exp \left[-2 R_{\mathrm{F} 10} t\right] \\
X_{1}(t)= & {\left[X_{1}(0)+2 X_{2}(0)\left(1-\exp \left[-R_{\mathrm{F} 10} t\right]\right)\right] } \\
& \times \exp \left[-R_{\mathrm{F} 10} t\right] \\
X_{2}(t)+X_{1}(t)= & {\left[X_{1}(0)+X_{2}(0)\left(2-\exp \left[-R_{\mathrm{F} 10} t\right]\right)\right] } \\
& \times \exp \left[-R_{\mathrm{F} 10} t\right]
\end{aligned}
$$

が得られる、なお，式(38) を用いて得られるダブル・テザー 全体の残存率は, Pardini ら ${ }^{18)}$ によって得られたダブル・ テザー全体の残存率18) と等価であることを付記しておく．

\section{4. スペース・デブリ環境モデル}

テザーのスペース・デブリに対する残存率を評価するた めには，個々のスペース・デブリの質量，サイズ，材質， 形状, 速度といった物理特性を記述するモデルが必要とな る . このようなモデルを工学モデルというが, 米国航空宇 
宙局 (NASA) の ORDEM 2000 と欧州宇宙機構 (ESA) の MASTER 2001 のふたつのモデルか現在幅広く利用さ れている.本論文でも，このふおたつのモデルを用いてテザー の残存率を評価した . 以下に ,このふたつのモデルについ て簡潔に説明する。

まず, ORDEM (Orbital Debris Engineering Model) についてであるが，これについてはべースとなっている Kessler モデルを説明した方がよかろう. 米国の宇宙ステー ション計画が進捗する中 , デブリ・フラックスの長期予測 がどうしても必要であった . NASA では光れまでに得られ たデブリ環境のデータを取りまとめ，また，デブリ軌道の 変化などにはある程度の数学的モデルを適用して, フラッ クスの統一的記述を試みた .これが Kessler モデルである これには，軌道上物体のデータ (カタログに収録されたも のと，収録待ちを含む，地上設置望遠鏡・レーダの観測結 果, Solar Maximum Mission Satelliteや Long Duration Exposure Facility の回収表面の衝突痕分布などが反映さ れている.取り込まれたデータの性格上，このモデルは高 度 $2000 \mathrm{~km}$ 以下でしか有効でない 。

米国スペース・シャトルの密の衝突痕分布を Kessler モ デルが低く見積もるようになったため，これを補正したの が ORDEM である .

次に MASTER (Meteoroid and Space Debris Terrestrial Environment Reference Model) であるが, MASTER では, 過去の事象に基づき，スペース・デブリの生成 原因ひとつひとつを記述する詳細モデルに基づいてスペー ス・デブリを生成して特定の軌道に配置し, 光れらの軌道 の経年変化を計算して得られるスペース・デブリ環境から， 時間, 高度 , デブリのサイズの関数としてのスペース・デ ブリのフラックスなどを計算している．組み込まれている 生成原因としては, 打上げ, 爆発・衝突などの破砕だけで なく, 固体口ケット燃焼時のアルミナ粒子の放出, ROSAT 衛星の冷却剂の放出, 表面劣化によって剥離したペイント 片といった破砕以外の生成原因も考慮されている．また，

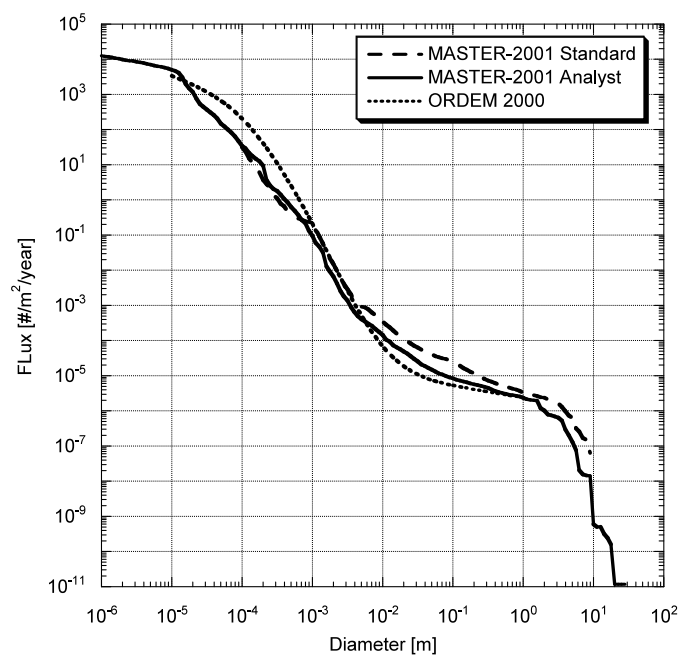

第 6 図 デブリ・フラックス
Divine-Staubach 流星モデルや Jenniskens/McBride 流星 雨モデルを組み込んで, 宇宙塵も考慮できるようになって いる、計算から得られる軌道環境は，観測から得られた軌 道環境と比較することにより，デブリ生成原因の各種モ一 ドが過去の事象に基づいて適切に計算されているか , など を確認し，モデルの信頼性を高めている．

QTEX のミッション軌道は, 高度 $800 \mathrm{~km}$, 軌道傾斜角 98 度の太陽同期軌道で, 2006 年夏期の打上げを目標に開発が 進められている .この条件で MASTER-2001 と ORDEM 2000 を用いて得られたスペース・デブリ環境 (フラックス) を第 6 図に示す . MASTER-2001には, Standard モード と Analyst モードのふおたつのモードがあるが，本論文では 後者の Analyst モードの結果を用いた .

低軌道におけるスペース・デブリの飛来方向は，一般に仰 角が小さく，ほぼ水平方向から飛来することが分かってい る. 乥のためフラックスを方位角のみの関数として考えて もよい．この場合，極座標にプロットしたフラックス分布 は, 進行方向に対して左右対称な蝶々形になることが知ら れている.テザーへの衝突確率を計算する際には, シング ル・テザーは安定状態て鉛直方向に軸対称であるから，デブ リのフラックスは方位角に関する平均值で考えてよい．各 ブル・テザーでは進行方向に対する 2 本のテザーの配置に よって衝突率が変化することになるが, テザーの巻き癖の 影響や，両端衛星のヨ一運動によって，容易に捻れを生じ ると予想されるので, テザー全長にわたって考えると，こ の場合も方位角の影響は平均化して取り扱ってもよい．

\section{5. 計 算 結 果}

第 1 表に示すように，本論文で炎の残存率を評価するテ ザーの直径は $0.33 \mathrm{~mm}$ である. このテザーを用いて，第 3 図に示すようなダブル・テザーを構成した場合の残存率を評 価する . また ，ダブル・テザーの有効性を検討するために， ダブル・テザーと断面積 (あるいは質量) が同じとなる直径 $0.47 \mathrm{~mm}$ のシングル・テザーの残存率についても評価する なお，有効衝突断面積を評価するにあたり， $D_{\mathrm{TC}}=0.7 D_{\mathrm{T}}$ および $d_{\mathrm{C}}=D_{\mathrm{T}} / 3$ とする.すなわち , テザーの直径の 3 分の 1 以上のサイズのスペース・デブリの一端が , テザーの 中心から $0.35 D_{\mathrm{T}}$ 以内に衝突したら，切断すると仮定する

第 7 図および第 8 図は直径 $0.47 \mathrm{~mm}$ のシングル・テザー (ST) の残存率 (図中の破線) と直径 $0.33 \mathrm{~mm}$ のテザーで 構成されるダブル・テザー (DT) の残存率 (図中の点線と 実線) の時間変化を示している.点線はループの隙間がな い場合，すなわち 2 本のテザーか離れずに接している場合 $\left(h / D_{\mathrm{T}}=1\right)$ の残存率で, 2 本のテザーが同時に切断され る可能性が高いため, シングル・テザーの残存率と比較し ても，あまり延命効果か現れていない，また，図中のシン

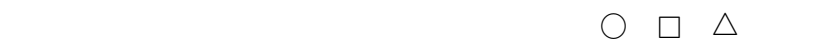
光れ結び目の間隔が $5 \mathrm{~m}, 10 \mathrm{~m}, 100 \mathrm{~m}$ の残存率であるが， 谷の効果はあまり見受けられない，一方，実線はループの 隙間が無限に離れている場合 $\left(h / D_{\mathrm{T}}=\infty\right)$ の残存率であ るが , この場合 2 本のテザーは同時に切断されることはな 

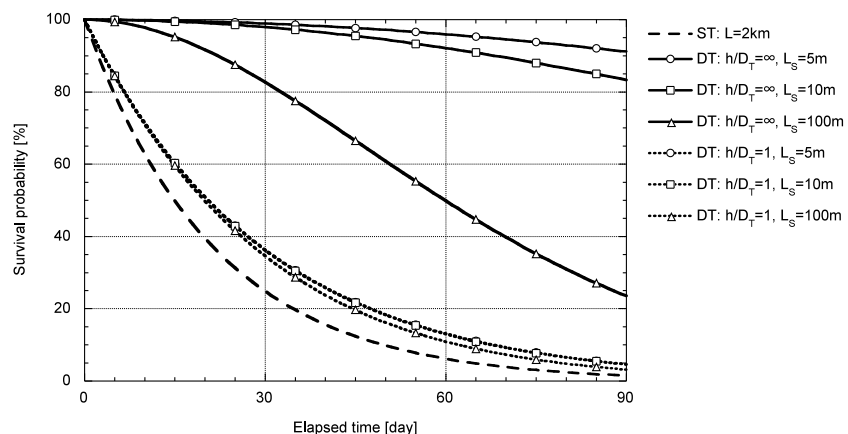

第7図 シングル・テザー $(\mathrm{ST})$ とダブル・テザー $(\mathrm{DT})$ の残存率 の時間変化 (MASTER-2001)
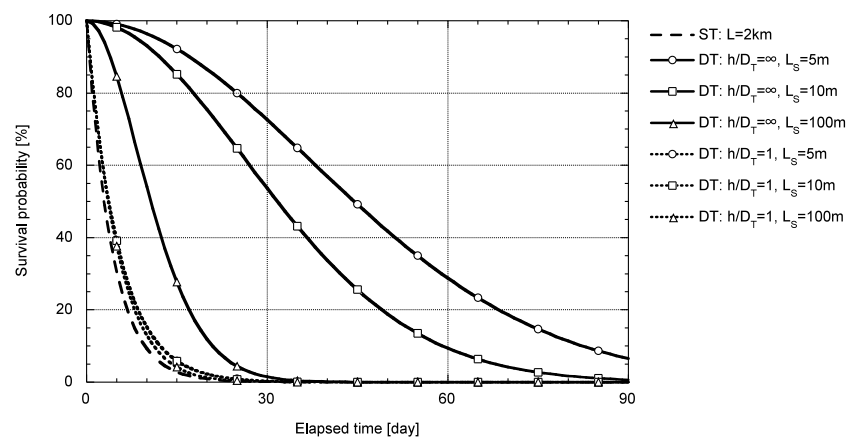

第 8 図 シングル・テザー $(\mathrm{ST})$ とダブル・テザー $(\mathrm{DT})$ の残存率 の時間変化 (ORDEM 2000)

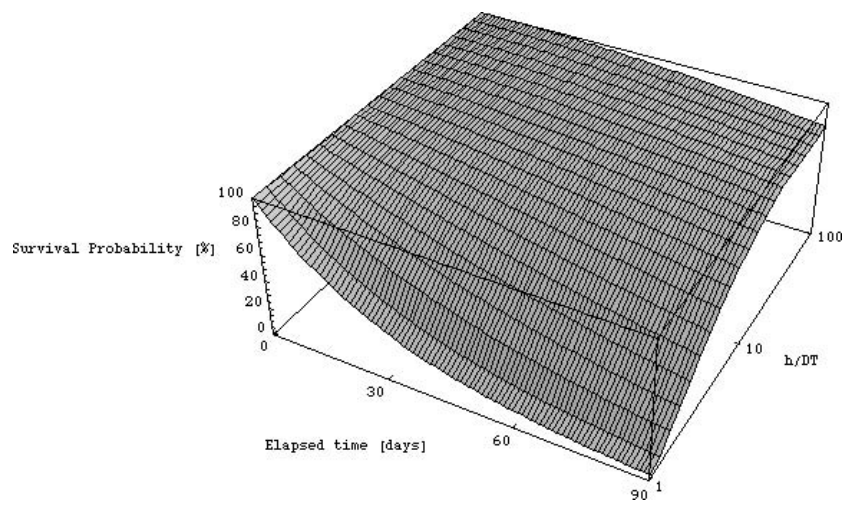

第 9 図 時間とループの隙間の関数としてのダブル・テザーの残存率 の 3 次元プロット (MASTER-2001)

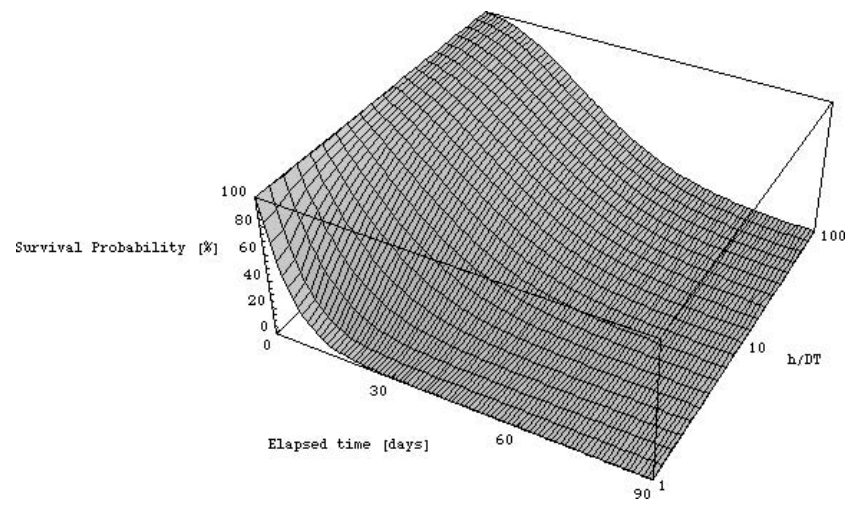

第 10 図 時間とループの隙間の関数としてのダブル・テザーの残存 率の 3 次元プロット (ORDEM 2000)

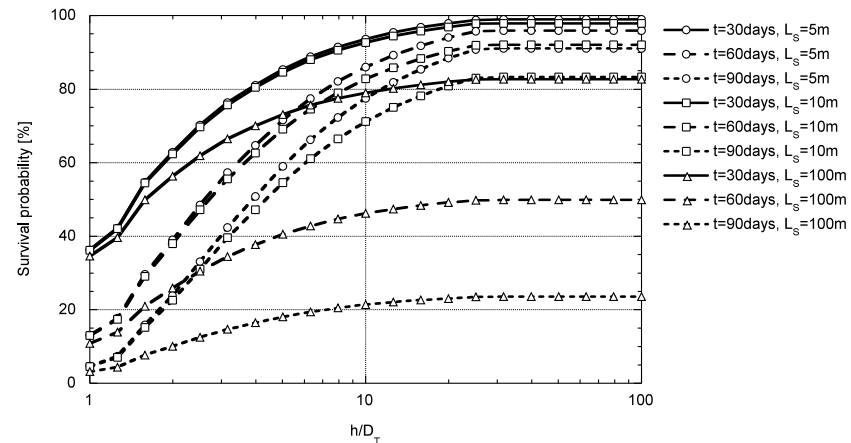

第 11 図 ミッション開始 30 日後, 60 日後および 90 日後のダブル・テ ザー残存率におけるループの隙間の効果 (MASTER-2001)

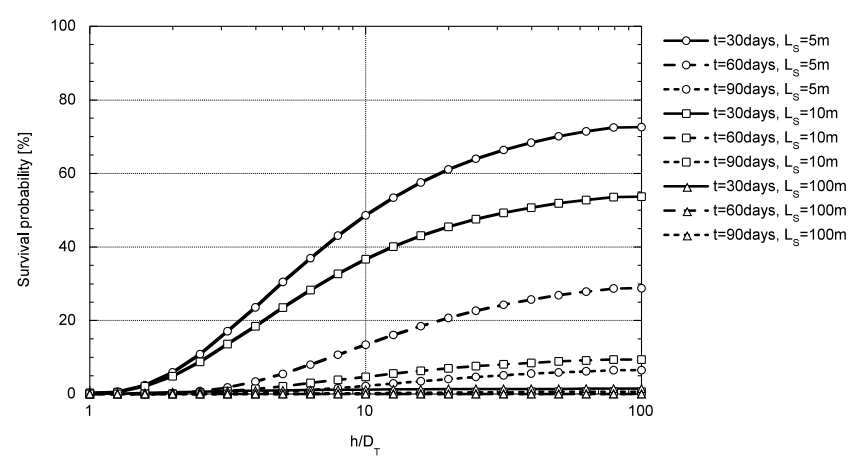

第 12 図 ミッション開始 30 日後, 60 日後および 90 日後のダブル・テ ザー残存率におけるループの隙間の効果 (ORDEM 2000)

いので , かなりの延命効果が期待できる．また，結び目の 間隔の効果も顕著に現れており, 結び目の間隔が小さい程 延命効果が高くなることが分かる .

第 9 图および第 10 図は, 時間とループの隙間の関数とし て , ダブル・テザーの残存率を 3 次元的にプロットしたも のである.なお, 結び目の間隔は $5 \mathrm{~m}$ である.本来は, 第 9 図および第 10 図を用いてダブル・テザーを設計するのが最 良と考えるが , ダブル・テザーの残存率におけるループの 隙間の効果を詳細に検討するために，第 9 図および第 10 図 からミッション開始 30 日後 (図中の実線)，60日後 (図中 の破線) および 90 日後 (図中の点線) のダブル・テザーの 残存率を取り出して, ループの隙間の関数として再プロッ 卜したのが第 11 図および第 12 図で, 結び目の間隔が $10 \mathrm{~m}$ と $100 \mathrm{~m}$ のダブル・テザーの残存率も一緒にプロットして ある. MASTER のスペース・デブリ環境を用いて計算し た第 11 図では, ループの腺間がテザー直径の約 25 倍以上 となると，ループの隙間の効果が見られなくなる．本論文 では, テザーの直径を $0.33 \mathrm{~mm}$ としているので, ループの 隙間が約 $8 \mathrm{~mm}$ 以上であれば , ループの隙間が無限の場合 の残存率と同じ結果になる．現実問題として，この程度の 隙間は， 2 本のテザーの一方を長くすることによって，対応 可能である . ORDEM のスペース・デブリ環境を用いて計 算した第 12 図では, ループの隙間がテザー直径の約 80 倍 (約 $25 \mathrm{~mm}$ ) 以上とならなければ，ループの隙間の効果が なくならないが, 工学的に対応可能な隙間であると考える． 


\section{6. 結}

言

本論文では, ダブル・テザーの残存率の評価において , ダ ブル・テザーのループを構成する 2 本のテザーを弚れ独 立のシングル・テザーとして取り扱う手法と異なり，ループ を構成する 2 本のテザーが同時に切断される可能性を考慮 した新しい手法を確立した .また，この手法を九州大学で開 発中の小型テザー衛星 QTEX に適用し，MASTER-2001 と ORDEM 2000 のふたたのスペース・デブリ環境モデル を用いて，光の残存率を評価した。㫕の結果，以下の知見 が得られた。

1) ループ数が十分多く，またループの隙間が十分に大き いダブル・テザーを採用すれば，かなりの延命効果が期待 できる .

2) 用いるスペース・デブリ環境モデルにより残存率がか なり異なる.MASTER-2001 を用いた結果では高い残存率 を示した一方，ORDEM 2000 を用いた結果では小さい残 存率を示した。

本論文では, ダブル・テザーのループを構成する 2 本の テザー光れ㐌れに有効衝突断面積を考え，ふたつの有効衝 突断面積が重なる部分においてのみ, 2 本のテザーが構成 するループの隙間によらず， 2 本のテザーが同時に切断さ れると仮定している．この仮定では， 2 本のテザーが十分 に離れており， 1 本目のテザーを切断したスペース・デブ リ(あるいは 1 本目のテザーに衝突した際に気化・液化し たスペース・デブリとテザーの断片) が，すでに 2 本目の テザーを切断するエネルギーを有しない場合でも， 2 本の テザーは同時に切断されることになる．つまり，本論文の

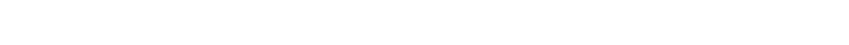
は明らかである．逆に，1 本目のテザーに衝突した際に気 化・液化したスペース・デブリとテザーの断片がある広が りを有して 2 本目のテザーに衝突することを考えると，た とえエネルギーが分散されたとしても，2 本目のテザーは 広く損傷を受け，本論文の仮定よりも切断され易いかもし れない．この場合は，ダブル・テザーの残存率を過大に見 積もることになる．ダブル・テザーを対象にした超高速衝 突の実験例が全くない現状では，信頼できる軌道上残存率 の評価法は無いと言っても過言ではない . 残存率評価の信 頼度を向上させるためにも，ダブル・テザーを対象にした 超高速衝突実験を検討したい。

本研究の一部は, 日本学術振興会科学研究費補助金基盤 研究 $(\mathrm{S})$ 課題番号 15106013 の支援の下実施されたことを 付記するとともに感謝の意を表す．

\section{参 考 文 献}

1) Beletskii, V. V. and Levin, E. M.: Dynamics of Space Tether Systems, Adv. Astronaut. Sci., 83 (1993), pp. 267-322.

2) Tanaka, Y., Kawamura, T., Hirayama, H. and Yasaka, T.: The Dynamics of Inter-Orbital Elevator Verification Satel- lite, Paper ISTS 2004-d-19, 24th International Symposium on Space Technology and Science, Miyazaki, Japan, 2004.

3) Forward, R. L., Hoyt, R. P. and Uphoff, C.: Application of the Terminator Tether Electrodynamic Drag Technology to the Deorbit of Constellation Spacecraft, AIAA Paper 983491, AIAA/ASME/SAE/ASEE 34th Joint Propulsion Conference, Cleveland, OH, 1998.

4) 西峯明子 : テザーへのデブリの衝突解析，平成 12 年度九州大学 学士論文, 2001 .

5) Nishimine, A.: Debris Collision Analysis for Tethers, Proceedings of the 23rd International Symposium on Space Technology and Science, Matsue, Japan, 2002, pp. 2524-2529.

6) 大石 篤: テザーを用いた De-Orbit におけるスペース・デブリ 衝突解析に関する研究, 平成 15 年度九州大学学士論文, 2004 。

7) Pardini, C.: Overview of Space Tether Applications: Stateof-the-Art Knowledge and Tools, Proceedings of the 21st IADC Plenary Meeting, ISRO on CD-ROM, Bangalore, India, 2003.

8) Pardini, C.: De-Orbiting Spacecraft with Electrodynamic Tether Devices, Proceedings of the 21st IADC Plenary Meeting, ISRO on CD-ROM, Bangalore, India, 2003.

9) Pardini, C.: Potential Benefits and Risks of Using Electrodynamic Tethers for End-of-Life De-Orbit of LEO Spacecraft, Proceedings of the 21st IADC Plenary Meeting, ISRO on CD-ROM, Bangalore, India, 2003.

10) Ooishi, A., Hirayama, H., Hanada, T., Yasaka, T., Pardini, C. and Anselmo, L.: Assessment of Collision Risk to Electrodynamic Tether Used for De-Orbiting, Paper IAC04-IAA.5.12.5.09, 55th International Astronautical Congress, Vancouver, Canada, 2004

11) Hirayama, H., Oishi, A., Hanada, T. and Yasaka, T.: Survivability of Double Tether for 'QTEX,' Paper COSPAR 04A-03704, 35th COSPAR Scientific Assembly, Paris, France, 2004.

12）西原秀信 : 超小型衛星 D-TES の開発一システム設計一, 平成 9 年度九州大学修士論文, 1998 。

13）坂本祐二, 中村揚介, 高木 望, 重松公平, 大林泰隆: 超小型テザ一 衛星 QUEST (Kyushu-U.S. Experimental Satellite Tether) の 開発計画，第 43 回宇宙科学技術連合講演会講演集, $1999, \mathrm{pp}$ $1365-1370$.

14) Nakamura, Y. and Carlson, H.: The Kyushu/US Experimental Satellite Tether (QUEST) Mission - a Small Satellite to Test and Validate Spacecraft Tether Deployment and Operations--, Proceedings of the 14th AIAA/USU Conference on Small Satellite, 2000, pp. 315-327.

15) Takaki, N., Carlson, H., Nakamura, Y., Obayashi, Y., Sakamoto, Y., Shigematsu, K., Hirayama, H., Egan, L., Mottola, M., Wolfe, J., Reed, H., Kitts, C. A. and Yasaka, T.: The Kyushu/US Experimental Satellite Tether (QUEST) Mission - a Small Satellite to Test and Validate Spacecraft Tether Deployment and Operations-, Proceedings of the 22nd International Symposium on Space Technology and Science, Morioka, Japan, 2000, pp. 2336-2341.

16) Kuwahara, T., Yasaka, T., Hanada, T., Hirayama, H., Sakamoto, Y. and Itahashi, T.: Kyushu University MicroSatellite QTEX Project, Paper IAC-04-IAA.4.11.5.06, 55th International Astronautical Congress, Vancouver, Canada, 2004.

17）板橋孝昌, 平山 寛, 八坂哲雄: 超小型テザー衛星 QTEX (1) プ ロジェクト概要，第 48 回宇宙科学技術連合講演会講演集，2004， pp. 819-824.

18) Pardini, C., Anselmo, L., Hanada, T. and Hirayama, H.: Assessing the Vulnerability to Debris Impacts of Electrodynamic Tethers during Typical De-Orbiting Missions, Paper SPACE 2005-A-00009, 4th European Conference on Space Debris, Darmstadt, Germany, 2005. 